Volume 8

Number 12008

Article 1

December 2008

\title{
Tubman Versus Hodgson: A Conversation About Abortion
}

Nicole Brewin

Cedarville University

DigitalCommons@Cedarville provides a publication platform for fully open access journals, which means that all articles are available on the Internet to all users immediately upon publication. However, the opinions and sentiments expressed by the authors of articles published in our journals do not necessarily indicate the endorsement or reflect the views of DigitalCommons@Cedarville, the Centennial Library, or Cedarville University and its employees. The authors are solely responsible for the content of their work. Please address questions to dc@cedarville.edu.

\section{Recommended Citation}

Brewin, Nicole (2008) "Tubman Versus Hodgson: A Conversation About Abortion," CedarEthics: A Journal of Critical Thinking in Bioethics: Vol. 8 : No. 1 , Article 1.

DOI: $10.15385 /$ jce.2008.8.1.1

Available at: http://digitalcommons.cedarville.edu/cedarethics/vol8/iss1/1 


\section{Tubman Versus Hodgson: A Conversation About Abortion}

Browse the contents of this issue of CedarEthics: A Journal of Critical Thinking in Bioethics.

Keywords

Abortion, Harriet Tubman, Dr. Hodgson

Creative Commons License

(c) (1) 8

This work is licensed under a Creative Commons Attribution-Noncommercial-No Derivative Works 3.0

License.

Follow this and additional works at: http:// digitalcommons.cedarville.edu/cedarethics

Part of the Bioethics and Medical Ethics Commons

This article is available in CedarEthics: A Journal of Critical Thinking in Bioethics: http://digitalcommons.cedarville.edu/cedarethics/ 


\title{
Tubman versus Hodgson: A Conversation About Abortion
}

\author{
Nicole Brewin \\ Cedarville University
}

Harriet Tubman: How amazing this country is!

Dr. Hodgson: I'm sorry?

Harriet Tubman: You have colored people and white people living together. Like the skin makes no difference! I didn't think it could happen. I thought there'd always be some hatred between white and black people.

Dr. Hodgson: Yes, we in this country believe in equality of all humanity. We hold to equal treatment and tolerance.

Harriet Tubman: Tolerance? How wonderful. When I was in this country last time there wasn't much tolerance of us colored folks.

Dr. Hodgson: Excuse me? When exactly were you in this country last?

Harriet Tubman: Well, I left in 1913.

Dr. Hodgson: 1913! You're kidding. Though your clothing fits the part. Oh! Now I see. You are a role-playing actress. What famous person are you playing?

Harriet Tubman: I swear I am not playing a part. You can call me Moses, lots of people did. Or if you rather, Harriet. It was my ma's name. Of course when I was a child they called me Minty (Bradford 1886).

Dr. Hodgson: Harriet ... Harriet . . . Oh yes! Harriet Tubman! I shall call you that if you wish. You are quite believable by the way. Such attention to detail...

Harriet Tubman: And who are you, sir?

Dr. Hodgson: My name is Dr. Jane Hodgson. I am a doctor of medicine here, and I mostly perform abortions.

Harriet Tubman: Abortions? I heard picketers on the way in. They said you kill babies?

Dr. Hodgson: No, no certainly not! What an offensive thing to say! I give women the choice to remove unwanted pregnancies. You see, I give women the freedom to terminate their pregnancies by disposing of fetuses. But I do not kill babies. A fetus is not a baby.

Harriet Tubman: I don't know much about science. I never had the right to an education. What 
is a fetus?

Dr. Hodgson: A fetus is an unborn offspring. From eight weeks until birth we call the offspring a fetus because it is not a child, but a collection of cells that is still developing ("Definition of Fetus," 1998).

Harriet Tubman: So the fetus is a baby that's still in the mother?

Dr. Hodgson: Essentially. I prefer to define it as an aggregation of cells that will become a child when born.

Harriet Tubman: So you're saying that when it is in the womb it is one thing, a not human thing, but when it is out of the womb it turns human. Science sure teaches some weird things!

Dr. Hodgson: The distinction is that the unborn fetus cannot live apart from its mother, while a child can.

Harriet Tubman: I never met a baby that didn't need its mama watching it. I even had to take to drugging the babies I helped to get freedom for. Babies still need their mamas (Bradford, 1886).

Dr. Hodgson: Babies need their mother for protection; fetuses need their mother in a much greater way. They're a leech on their mother's resources.

Harriet Tubman: And what do you think babies are? Babies are leeches too. And isn't it true that science made it so babies can live outside their mother at a real young age? Science made it so kids born too early to live in my day can now survive. So some of the babies you're killing could still live if you just took them out of the womb instead of killing them. Seems like when the baby comes out isn't a good way of knowing if it's human or not.

Dr. Hodgson: We cannot determine when the baby becomes a person, so as long as it is in the mother's uterus it is simply part of the mother.

Harriet Tubman: And the picketers said something about partial-birth abortion? So when you do those, you're killing something that's half human, half not?

Dr. Hodgson: The head is still in the mother. It is still a fetus.

Harriet Tubman: But with partial birth abortions it's more than halfway out of the mama. It's more like it's a little part of the mama, mostly its own self if you use your way of knowing it's human. And don't that baby have its own nature? Its body is separate from the mama's so it's not even part of the mama even when it's in the womb. Leastways that's what the picketers said.

Dr. Hodgson: Our government has laws that protect the rights of the mother. That's what's important. A woman must have a right to choose. The rights of the fetus are less significant.

Harriet Tubman: That argument sounds familiar. In my day the government had laws to protect 
the rights of slave holders. That's what was important to them back then. I was treated like property the way you treat an unborn baby as property. Didn't make me less human; don't make the baby less human.

Dr. Hodgson: I cannot believe you are comparing abortion to slavery! A fetus doesn't have selfawareness! It cannot live apart from its mother. It doesn't have creative capacities. It is not a person.

Harriet Tubman: You have ways of making it seem right. But so did the slave owners. They said I wasn't a person too. They said my dark skin and crooked hair were outer flaws giving proof that I had character flaws. They said we were closer to apes. They said we were a lesser race. We evolved differently and should be treated as less than human (Thompson, 2003).

Dr. Hodgson: Are you suggesting we remove laws protecting the mother and her rights?

Harriet Tubman: Hah! Some protection. I heard the picketers on the way in. They said abortion hurts mamas, but abortion places like this one don't tell the mama. They said something about cancer in the breasts. It happens more in women who got an abortion (Lawlor, 2009).

Dr. Hodgson: That's not very conclusive about breast cancer. It's hard to say much what is certain on that subject.

Harriet Tubman: They also said something about hurting future kids. The mama's womb don't hold her babies as well after an abortion.

Dr. Hodgson: Well, yes, abortion or any kind of uterine surgery may weaken the cervix for future pregnancies.

Harriet Tubman: What about depression? I seen lots of depression in my day. Makes sense to me that killing the baby could cause depression.

Dr. Hodgson: Pro-lifers claim that abortion causes post traumatic stress disorder. Things like nightmares, anniversary syndrome, and depression. I cannot comment on that either way. We value the privacy of women, which makes follow up after abortion difficult (Lawlor, 2009).

Harriet Tubman: When the owners had us as slaves, they didn't have none of this depression or cancer stuff. Seems like an abortion's not the safest thing for the mama. You're risking her health.

Dr. Hodgson: We are giving the mother the freedom to decide what to do with her own body. She can study the risks. That is the best we can offer: the right to choose.

Harriet Tubman: What about the baby's right to life?

Dr. Hodgson: I explained this. The fetus is not a person. But even if it was, often we'd be saving it from a less than desirable life. That's why we say, "Every child a wanted child." Most of the 
babies we abort have mothers that cannot support them. They would be born into a broken, inadequate, and poverty stricken family. We are helping both the mother and the fetus.

Harriet Tubman: Now that's got nothing to do with nothing. I know what happened to my people after we were freed. Some of us had nothing so we lived in ghettos. We formed gangs. Lots of us lived in poverty. Whites still hated us, kept us separate, were violent to us. Our life was not exactly what we wanted. But we were free. A baby may only be living with a poor mama. But at least it's living. You telling them they can't live „cause they'll be poor is like the white man telling us we can't be free „cause we'll be poor. Don't make no difference (Lipke, 2009).

Dr. Hodgson: It still doesn't matter. What matters is that the mother's rights are protected.

Harriet Tubman: The mamas can take care of themselves. Them babies can't do nothing for themselves.

Dr. Hodgson: Precisely. That was my point earlier, if you recall.

Harriet Tubman: So they're the ones who need protection, not the mamas. You said this country was based on equality. So even though that baby is different from you and me, it still should be protected. It still should be treated as equal. You also said something about tolerance; you ain't very tolerant of a baby's right to life.

Dr. Hodgson: We are certain the mother is a person. We cannot determine whether a fetus is a person, and that means the mother's rights come first. If that mother chooses to terminate a pregnancy that is her choice.

Harriet Tubman: So if it's okay for you to stick scissors in that baby's head and suck its brains out, it's okay for me to do that to you? The only difference is that baby can't stop you from doing it.

Dr. Hodgson: All medical procedures are gory and graphic when fully described. Giving details of the procedure to entice a gut-reaction is a cheap shot, and it will not work on me.

Harriet Tubman: Some of the people who let us slaves stay with them in the Underground Railroad were Quakers. Now, I don't agree with all they thought, but they were right in some way. They were believers in peace. What you're doing to that baby don't seem all that peaceful (MacNair, 1999).

Dr. Hodgson: Don't go getting all religious on me!

Harriet Tubman: And can't the baby feel its head being poked and its brains being sucked out? Those picketers said that a baby can start feeling in the second trimester (Deem, 2006). Does its pain not matter?

Dr. Hodgson: There has been a study that suggested that. But why are you so concerned with the 
fetus? You pro-lifers only care about the fetus. You have no compassion for the mother.

Harriet Tubman: I got compassion for the mother. I don't want that mother getting no cancer or depression. Anyway, the mama has choices outside abortions. She could have the baby and let someone else adopt it. Or she could keep it herself if she wants. She don't have to abort, but she also don't have to worry about caring for it.

Dr. Hodgson: I suppose there is no point in talking to you further, and I am quite busy.

Harriet Tubman: Okay, then. You have a good day now, Doctor.

Dr. Hodgson: You too, Harriet.

\section{References}

Bradford, S. (1886). Harriet Tubman, The Moses of Her People. Retrieved October 9, 2008, from http://www.spartacus.schoolnet.co.uk/USAStubman.htm

Deem, R. (2006). Do Fetuses Feel Pain During an Abortion?. Retrieved October 8, 2008, from http://www.godandscience.org/doctrine/fetal pain.html

Lawlor, J. (2009). Long Term Physiological and Psychological Effects of Abortion on Women. Central Illinois Right to Life. Retrieved October 7, 2008, from http://www.cirtl.org/syndrome.htm

MacNair, R. (1999). A Lively Concern: The Religious Society of Friends (Quakers). Retrieved October 6, 2008, from http://www.fnsa.org/fall98/macnair1.html\#C

Thompson, A. (2003). Scientific Racism: The Justification of Slavery and Segregated Education in America. Gaines Junction 1:1. Retrieved October 9, 2008, from http:/pat.tamu.edu/journal/vol-1

(1998). Definition of Fetus. Retrieved October 10, 2008, from http://www.medterms.com/script/main/art.asp?articlekey $=3424$

Lipke, A. (2009). Between Civil War and Civil Rights. Race with History Web Site. Retrieved October 12, 2008, from http://www.racewithistory.org/html/bcwcr.html 